\section{League of Arab States}

Origin. The League of Arab States (often referred to as the Arab League) is a voluntary association of sovereign Arab states, established by a Pact signed in Cairo on 22 March 1945 by the representatives of Egypt, Iraq, Saudi Arabia, Syria, Lebanon, Jordan and Yemen. It seeks to promote closer ties among member states and to co-ordinate their economic, cultural and security policies with a view to developing collective co-operation, protecting national security and maintaining the independence and sovereignty of member states, in order to enhance the potential for joint Arab action across all fields.

Members. Algeria, Bahrain, Comoros, Djibouti, Egypt, Iraq, Jordan, Kuwait, Lebanon, Libya, Mauritania, Morocco, Oman, Palestine, Qatar, Saudi Arabia, Somalia, Sudan, Syria*, Tunisia, United Arab Emirates and Republic of Yemen. Observers. Brazil, Eritrea, India and Venezuela. ${ }^{\star}$ Membership suspended since Nov. 2011 after calls for the government to end violence against civilian protesters by a set date were ignored.

Aims and Activities. In the political field, the League is entrusted with defending the supreme interests and national causes of the Arab world through the implementation of joint action plans at regional and international levels. It examines any disputes that may arise between member states with a view to finding a peaceful resolution. The Joint Defence and Economic Cooperation Treaty signed in 1950 provided for the establishment of a Joint Defence Council as well as an Economic Council (renamed the Economic and Social Council in 1977). Economic, social and cultural activities constitute principal and vital elements of the joint action initiative.

Against the backdrop of the 2011 Arab Spring, the League backed a UN resolution authorizing action in Libya against Col. Gaddafi's air defences and suspended Syria for its government's oppression of the opposition movement. At the 2012 Arab League summit, Syria's seat was granted in principle to the opposition, although it remained vacant as of Feb. 2015. In March 2014 Secretary-General Nabil el-Araby had stated that it would not be filled until the opposition had completed the formation of its institutions. In 2011 the League supported a Palestinian bid for UN recognition and in 2014 championed an unsuccessful move to push through a UN resolution calling for an Israeli-Palestinian peace deal within 12 months and the withdrawal of Israeli troops from the disputed territory by 2017.

Arab Common Market. An Arab Common Market came into operation on 1 Jan. 1965. Initial plans to abolish customs duties on agricultural products, natural resources and industrial products by incremental reductions never came to fruition although the concept remains an ambition shared by many people in the Arab world.

Organization. The machinery of the League consists of a Council, 11 specialized ministerial committees entrusted with drawing up common policies for the regulation and advancement of cooperation in their fields (information, internal affairs, justice, housing, transport, social affairs, youth and sports, health, environment, telecommunications and electricity), and a permanent secretariat.

The League is considered to be a regional organization within the framework of the United Nations at which its SecretaryGeneral is an observer. It has permanent delegations in New York and Geneva for the UN and in Addis Ababa for the African Union (AU), as well as offices in a number of cities throughout the world.

Headquarters: Al Tahrir Square, Cairo, Egypt.

Website: http://www.lasportal.org

Secretary-General: Nabil el-Araby (Egypt).

\section{Further Reading}

Bouhamidi, Soumia, The Role of the League of Arab States: Mediating and Resolving Arab-Arab Conflicts. 2011

Gomaa, A. M., The Foundation of the League of Arab States. 1977

Salem, Ahmed Ali, International Relations Theories and Organizations: Realism, Constructivism, and Collective Security in the League of Arab States. 2008

\section{Organization of Arab Petroleum Exporting Countries (OAPEC)}

Established in 1968 to promote co-operation and close ties between member states in economic activities related to the oil industry; to determine ways of safeguarding their legitimate interests, both individual and collective, in the oil industry; to unite their efforts so as to ensure the flow of oil to consumer markets on equitable and reasonable terms; and to create a favourable climate for the investment of capital and expertise in their petroleum industries.

Members. Algeria, Bahrain, Egypt, Iraq, Kuwait, Libya, Qatar, Saudi Arabia, Syria, Tunisia ${ }^{\star}$, United Arab Emirates. ${ }^{\star}$ Tunisia’s membership was made inactive in 1986.

Headquarters: PO Box 20501, Safat 13066, Kuwait.

Website: http://www.oapecorg.org

Secretary-General: Abbas Ali Naqi (Kuwait).

Publications. Secretary General's Annual Report (Arabic and English editions); Oil and Arab Co-operation (quarterly; Arabic with English abstracts and bibliography); OAPEC Monthly Bulletin (Arabic and English editions); Energy Resources Monitor (Arabic); OAPEC Annual Statistical Report (Arabic/English).

\section{Organization of the Petroleum Exporting Countries (OPEC)}

Origin and Aims. Founded in Baghdad in 1960 by Iran, Iraq, Kuwait, Saudi Arabia and Venezuela. The principal aims are: to unify the petroleum policies of member countries and determine the best means for safeguarding their interests, individually and collectively; to devise ways and means of ensuring the stabilization of prices in international oil markets with a view to eliminating harmful and unnecessary fluctuations; and to secure a steady income for the producing countries, an efficient, economic and regular supply of petroleum to consuming nations, and a fair return on their capital to those investing in the petroleum industry. It is estimated that OPEC members possess $75 \%$ of the world's known reserves of crude petroleum, of which about twothirds are in the Middle East. OPEC countries account for about $43 \%$ of world oil production (55\% in the mid-1970s).

Members. (Feb. 2015) Algeria, Angola, Ecuador, Iran, Iraq, Kuwait, Libya, Nigeria, Qatar, Saudi Arabia, United Arab Emirates and Venezuela. Membership applications may be made by any other country having substantial net exports of crude petroleum, which has fundamentally similar interests to those of member countries. Gabon became an associated member in 1973 and a full member in 1975 , but in 1996 withdrew owing to difficulty in meeting its percentage contribution. Ecuador joined the Organization in 1973 but left in 1992; it then rejoined in Oct. 2007. Indonesia joined in 1962 but left in 2008 as it had ceased to be an oil exporter. 